\title{
SHIFTING PARADIGMS OF THOUGHT AND POWER
}

\author{
Alejandro BENDAŇA, ${ }^{29}$ \\ Founder of the Center of International Studies, Managua
}

\begin{abstract}
The article argues that a shift in paradigm is required away from the free market. The key question is if we are brave enough to call ourselves collectively and individually to moral and social accountability. And to acknowledge that it is our failure to act and speak up that leads to the escalating inequalities, poverty and oppression of today.
\end{abstract}

Keywords: NG0, IMF, World Bank, power, democratic institutions

\section{Policy, Politics and Power}

Trying to convince policymakers to think differently about development presupposes one of two options: (i) that attaining development with and through social justice is simply a question of adjusting present policies, or (ii) that policy changes are not enough, what is required is a shift in paradigm. And a shift in paradigm requires a shift in power. Ideas are shaped by politics, and not the other way around. The 'free market' is a political statement, not an economic one. It is at the core of the dominant paradigm. We therefore must address the politics and the paradigm if we are to understand policy. The paradigm needs to be deconstructed as part and parcel of the construction of a new one. At the level of theory, unfortunately the multiplication of disciplines and the development-related discussions within them (and occasionally across them) often do not contribute to the type of understanding and conceptual clarity demanded by practitioners on the ground on the one hand, or policymakers in the Northern capitals on the other. In the South, observable social realities make sharp demands on the articulation of theory and models. However, those same demands are often interpreted as threats by policymakers often more concerned with containing and eradicating those threats than in understanding the dynamics and determinants of development and conflict. The aid industry, for its part, tends to act within the limits that the rich country donor system imposes, which tends to coincide with the limits that are good for careers. The prospects therefore for a three-way meaningful dialogue are dim, at least at this point in time.

Could a common moral ground form the basis for dialogue? Can we call ourselves collectively and individually to moral and social accountability? Are we brave enough to admit, as one international agricultural consultant did, that 'it is individuals who cause poverty, underdevelopment and famine, by their actions, by their failure to act, and by their failure to speak up' (Griffiths, 2003). Dealing with the subject of impoverishment, war and in- justice is not a 9-to-5 proposi-

29 Contact address: bendana.alejandro@gmail.com 
tion. Global social reality must elicit a commonly shared and pervasive sense of personal ethical outrage. There will be no constructive dialogue if we are not able to share a sense of outrage over how decisions and mindsets far from the 'field' can kill (or save) many more times than wars do, particularly if we consider how many wars are started. Cannot passion and cold analysis combine to recognize that the current paradigm/power line-up is responsible for the untold direct and structural violence and suffering endured on a daily basis by a majority of the world's inhabitants?

\section{Combining passion with indicators}

How do we visualize and identify non-violent paths to social and global equity, the substance ostensibly of development? Analytical observation and ethical passion can again combine to provide outlines of new paradigms and alternatives. However, the 'what' is as important as the 'how': the politics of resistance is a fundamental underpinning for the construction of alternatives. Can policymakers and academics join in the politics of resistance? Or are they on the other side of the fence? Street engagement and civil disobedience have a way of shaping analysis. Alternatives are born continuously in the course of resistance. There are no alternatives without resistance, just as there is no effective resistance without alternatives. We believe therefore that the new paradigms are shaped by the practice of solidarity. Unfortunately, governments and institutions are, by nature, incapable of feeling passion save perhaps for self-perpetuation. Everyone claims to believe in justice, but justice is about putting the right institutions, policies and laws in place ('good governance'), as if building justice were a managerial task. Or as the heads of the IMF and World Bank insist, globalization can work for the poor if only we make a few adjustments here and there. Such a discourse is both boring and sad, because no small amount of strength and power are derived from the mobilization of passion for justice. Individuals as human beings, not as officials or NGO professionals, can enhance livelihoods. Relational power, first and foremost, with the dispossessed, will be the basis of a new paradigm. Or it will not be new at all.

of course, there will be always those who, annoyingly always and correctly sometimes, demand that we come up with indicators of change in our case, the power of passion. In the construction of alternatives, our first indicators of a materializing blueprint will be the scope and nature of resistance. The passion for justice cannot and should not be separated from the passion against injustice, that is to say resistance. The dominant paradigm invites us to take satisfaction in declarations, conventions, citizen participation in campaigns, favourable media coverage and progressive legislators. But the paradigm shift will not be measured by high-sounding resolutions or rock concerts, but by a change in the living conditions and ethos in real communities outside Managua, Manila or Maputo. If our campaigns or conferences do not assume these social indicators, then we are part of the problem, failing to speak up and allowing justice to become yet another commodity entrusted to the market and the corporations.

\section{Contesting the dominant paradigm}

Steve Biko, the great South African nationalist, once said: 'The most potent weapon in the hands of the oppressor is the mind of the Oppressed.' That weapon must be neutralized, and 
relying on the system's own blunders (Iraq or Enron) is not enough. Contesting the United States-led domination entails recognizing that hegemony is never static but requires constant legitimization and readjustment - including the admission of limited blunders - in order to insure its domination, legitimacy and reproduction. If we do not believe that contesting it is possible, then it is not even probable. The neo-liberal paradigm strives to assure even its critics that it basically has got things right, that like the market or the weather it is the natural order of things, admitting no alternative. Acceptance of such 'inevitability' goes to the heart of colonialism and domination entailing the construction of an empire where resort to military imposition is kept at a minimum. There is no one 'alternative' or set of prescriptions. Strategies will vary over the course of geography and historical time. Trying to universalize tactics - be it lobbying or street resistance - would be a serious mistake. But this need not mean shying away from the task of sharing strategic perspectives. The goal is to create countervailing and constructive global power capable of projecting itself strategically, as for example in the world-wide protests on 15 February 2003 against the War on Iraq. Networking is not an end in itself, but a means to an end in support of those in the forefront of resistance and in defence of intellectual and political spaces indispensable for the creation of new paradigms and new struggles. To contest the dominant paradigm is to contest the power it upholds. This is what will distinguish policy discussions from political ones. Therein lies the only realistic basis for serious discussion. Unfortunately policy people are by and large unwilling and unable, by definition, to question the very hand that feeds them. Dialogue with policy-makers, unwilling to question their own neo-liberal fundamentalism, becomes a waste of time at best, and counterproductive at worst as concessions are made for the sake of something called 'access' while officials rake in public relations points. There is no point in dialogue for the sake of dialogue (as if real give and take were anticipated) when, as the SAPRIN and other exercises show, there is no interest in fundamental change. Officials demand 'informed' dialogues, which is to say dialogue using their information and within their broader paradigm of making superficial change in order to avoid fundamental change. For many the goal is to deepen instead of alleviating the crisis of illegitimacy faced by the institutions and their development paradigm.

\section{Liberating the discourse}

Discourse and vocabulary are tools of hegemony and therefore a field of contention in itself. One indication of power is the pervasive influence of the Washington Consensus' discourse, dutifully assumed by academics and media pundits as they go about espousing notions of 'free market' or 'failed states'. Control over discussion terms leads quickly into control over discussion contents, making effective challenges all the more difficult. Unfortunately or revealingly, the neo-liberal globalization discourse has stolen its terms from its opposition, robbing terms such as empowerment, participation, gender and others, throwing them back at us devoid of their original social meaning. What is worse is our own assimilation of the Orwellian double-speak that pervades fundamentalist development thinking. Thus even critics of neo-liberalism tend to speak of liberalization where we mean deregulation; of reform where we mean reregulation (on 
behalf of big business); to privatize, which in effect means to monopolize public goods in fewer hands; of free trade where there is no freedom to export to protected markets in the North; of poverty reduction and not poverty eradication; of debt relief and re-structuring instead of debt cancellation or debt repudiation; of the illegitimate financial debt of the South and not the real ecological and social debt of the North to the South. (A counterpart in the military realm is 'humanitarian intervention' or 'conflict preemption'.)

The same discourse demands that we examine extreme poverty with the presumption that it has nothing to do with extreme wealth; indeed that the creation of new concentrated wealth will somehow benefit the poor. That poverty is a fact and not a process of impoverishment, and that impoverishment is not linked to exploitation and even more illicit process of capitalist enrichment and legalized theft of the common good. One should also refrain from repeating hypocritical sermons about corruption and good governance campaigns as framed by the international financial institutions to make the world more conducive to private investment and profit remittances. In the 'sea change' triumph ally announced in the form of the PRSP/PRGF package, we are asked to tinker with social policy as if it had nothing to do with economic policy, as if the best economic policy is not one which indeed requires no social safety net, because it is an economy of solidarity to begin with.

\section{Making the connections}

Analysing the pieces to death may prevent us from seeing the entire picture. Overly focused campaigns may be counterproductive when the links are not established, say for example, between debt and trade, IFIs and G8, military budgets and corporations, landmines and war, etc. At the level of both analysis and strategy, we must draw out the connections between the micro and macro, between poverty and globalization, between impoverishment and enrichment, between economics and politics, between capitalism and war. Positive envisioning must go beyond the normative to the organizational so as to explore, as the World Social Forum processes have, the possibilities and potentials, dynamics and determinants of building alliances and mobilizing people. What is crucial here is the capacity and determination to discern the way in which 'civil society' itself is a field of contention between those willing to live with a reformed status quo and those who find it entirely unsustainable and repugnant. This means having a hard look at the international and national NGOs that have been commissioned to help 'build capacities' to advocate reform, and those engaged in 'mobilizing capacity' to bring about structural change.

\section{The politics of engagement}

The prevailing development reality - judged in ethical human terms - can only lead us to the conclusion that mainstream development theory is bankrupt. The failure is not one remedied by improved social mitigation mechanisms in the hegemonic development model, rather it is a question of conceiving an economic growth as a social process, where social mitigation is a principal byproduct and not a sideline corrective mechanism. The best 'social policy' is a humane development/growth policy. 
For many of us it is difficult to conceive of sustainable alternatives without a participative (as opposed to vanguardist) recapture of the state, and increasingly a collective of states to help build counter-power. This should not mean the mindless defence of any particular government that quarrels with the North, but instead the defence of key state development instruments that the 'free traders' wish to negotiate away.

Development is too important to be left to the development specialists. Macro-economics cannot be divorced from macro-politics. The social dysfunction of predominant development thinking is intertwined with the extremism that characterizes United States policy. Can we conceive of a shift in development theory and practice without a corresponding change in the loath some political theory or practice in Washington power circles? New development thinking, in this context, is part and parcel of the task of building resistance to the United States imperial undertaking.

\section{Conclusions}

If the unacceptable status quo is to be effectively challenged, as opposed to reinforced, if violent conflict and poverty stemming from mal- or non-development are to be eradicated (and not simply managed), then social scientists must join activists in exposing and de-legitimizing existing paradigms of power held by northern policy-makers. The linkages between trade, debt and militarism must be recognized. Opposition will not be effective if academic thought continues to grow inward upon itself, while policymakers re-sort to fundamentalist free market discourses. This means encouraging inter sectoral dialogue but in a way that privileges recognition of what should be the common denominator: the unacceptability of a world without justice. The challenge is to forge democratic instruments for the redistribution of wealth, and also for its production. Ideas are flourishing and a common underpinning is the realization that people must be in common and that states must be democratized by way of the democratization of the broader relationships among society, institutions and the market. ${ }^{30}$

A multitude of experiments are under way, albeit sometimes isolated from each other. One specific academic task is to disseminate these practices. But given the present disjointed scheme of affairs, the when may overtake the how, action may precede journal-submission ready thought.

For the time being, policy makers and activists will be more foes than friends, while academics may have to choose what side they are one, because the Empire is rapidly dissolving middle grounds. But with the exception of professional development lobbyists, no one need to shed tears over the terms of the divorce. The marriage was only as sustainable as the development theory itself. Alternatives will continue to be born, perhaps more soundly without the participation of so many midwives with their own agendas. The process is under way in the form of the growing global anti-corporate movement, which in itself is a necessary precondition for generating the vehicles for political action that finally leads to the renovation theory and perhaps policy. It is important, in this context, to support and mobilize around the World Social Forum, which is where

30 See for example the text and contributions of the Forum for the Cross-evaluation of Proposals for a Responsible, Plural and United World (http://propalliance.delibera.info.gb). 
the multitude of dissenting imaginations may just give way not only to alternative relationships but alternative political institutions geared to new people-oriented, rights-based development processes.

\section{References}

1. Griffiths, P. (2003), The Economist's Tale: A consultant encounters hunger and the World Bank, London: Zed Books. 